\title{
PENGGUNAAN PROPORTIONAL INTEGRAL DERIVATIVE ( PID ) CONTROLLER PADA FILTER AKTIF UNTUK MEREDAM HARMONISA AKIBAT BEBAN NON LINIER DI BALI NATIONAL GOLF RESORT
}

\author{
I Gusti Made Widiarsana ${ }^{1}$, I Wayan Rinas ${ }^{2}$, I Wayan Arta Wijaya ${ }^{3}$ \\ ${ }^{1,2,3}$ Program Studi Teknik Elektro, Fakultas Teknik, Universitas Udayana \\ Email: widiarsana168@yahoo.co.id ${ }^{1}$, rinas@unud.ac.id ${ }^{2}$, artawijaya@unud.ac.id $^{3}$
}

\begin{abstract}
ABSTRAK
Bali National Golf Resort memiliki tingkat penggunaan beban non linier yang tinggi . Tingginya penggunan beban non linier yang diopeasikan dapat menimbulkan harmonisa yang merupakan permasalahan utama dalam kualitas daya listrk. Harmonisa memiliki dampak buruk dalam sistem tenaga listrik yang menyebabkan bentuk gelombang arus dan tegangan tidak sinusoidal sehingga dapat mengakibatkan kondisi sistem kelistrikan tidak normal. Penggunaan filter aktif merupakan salah satu cara untuk meredam harmonisa. Penelitian ini memfokuskan pada simulasi penggunaan PID (proportional integral derivative) Controller pada filter aktif untuk meredam harmonisa. Dalam penelitian ini simulasi filter aktif menggunakan software MATLAB R2013. Hasil simulasi Penggunaan PID Controller pada filter aktif mampu meredam Kandungan $T H D$ di Bali National Golf Resort. Dimana Nilai $T H D_{i}$ setelah di pasang filter turun rata-rata menjadi $1.89 \%$ dan nilai $T H D_{V}$ turun rata-rata menjadi $0.59 \%$.
\end{abstract}

Kata Kunci : Harmonisa, Beban non linier, PID

\section{ABSTRACT}

Bali National Golf Resort has a high level of non-linear load usage. A harmonic is emerged due to a high level of non-linear load usage which was the main problem on the quality of electric power. On the other hand, it is also lead to an adverse impact for the electric power system such as the wave form and voltage were not sinusoidal. Then, in order to reduce it, an active filter could be used as one of the best way. This research focused on the simulation of PID (Proportional Integral Derivate) Controller towards an active filter to reduce the harmonic and MATLAB R2013 software that applicated as the instrument. As the result,the usage of PID Controller on the active filter could reduce the THDi into $1.89 \%$ and THDV into $0.59 \%$ as an average percentage at Bali National Golf Resort.

Keywords: Harmonics, Non linear loads, PID

\section{PENDAHULUAN}

Bali National Golf Resort merupakan salah satu tempat olah raga yang diperuntukkan bagi kalangan atas. Bali National Golf Resort banyak dikunjungi oleh wisatawan maupun kalangan pebisnis. Peralatan - peralatan yang banyak dioperasikan di Bali National Golf Resort resort seperti AC (air conditioner), Charger Boggie, Satelit Splinker, pompa dan lain sebagainya yang tergolong beban-beban non linier. Karena begitu banyaknya bebanbeban non linier yang dioperasikan, maka akan memungkinkan terjadinya distorsi harmonisa.

Salah satu cara untuk mereduksi harmonisa adalah dengan penggunaan filter. Salah satu filter yang digunakan untuk meredam harmonisa adalah filter aktif. Penggunaan filter aktif dalam mereduksi harmonisa telah banyak diteliti oleh beberapa pihak salah satunya penelitian yang dilakukan oleh Antonius Ibi Weking, I W. Rinas, dan A.K. Suwardana yang menggunakan simulasi penentuan penempatan filter aktif shunt pada Blue Point Bay Villa \& Spa [1]. 
Penggunaan filter aktif dengan berbagai macam metode kontrol saat ini banyak diteliti tetapi masih terdapat banyak kerumitan pada rangkaian kontrolnya. Metode Kontrol PID adalah salah satu solusi untuk mengatasi kerumitan pada rangkaian kontrol.

Berdasarkan pengukuran awal yang telah dilakukan didapatkan besarnya nilai $\mathrm{THD}_{\text {, tertinggi sebesar } 27,5 \% \text { dan }}$ terendah sebesar 13,6 \%, serta besarnya nilai $\mathrm{THD}_{\vee}$ tertinggi sebesar 2,7 \% dan terendah sebesar 1,1\%. Standar THDI sesuai dengan nilai rasio hubung singkat dan tabel standar IEEE 519 tahun 2014 adalah sebesar $5 \%$, maka dengan nilai

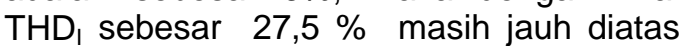
standar yang telah ditentukan. Standar THD $_{v}$ sesuai IEEE 519 tahun 2014 yaitu untuk suplai tegangan antara $1 \mathrm{kV}<\mathrm{V}<69$ $\mathrm{kV}$ adalah sebesar $5 \%$, dimana Bali Golf National Resort disuplai tegangan $20 \mathrm{kV}$ maka nilai $\mathrm{THD}_{\vee}$ masih memenuhi standar.

Penelitian ini dilakukan dengan penggunaan proportional integral derivative ( PID ) controller untuk meredam harmonisa akibat beban non linier dengan menggunakan software MATLAB.

\section{KAJIAN PUSTAKA}

\subsection{Harmonisa pada sistem tenaga} listrik

Harmonisa merupakan suatu fenomena yang terjadi akibat penggunaan beban listrik non linier. Harmonisa pada sistem kelistrikan merupakan salah satu penyebab yang mempengaruhi kualitas daya. Pengaruh adanya harmonisa sangat dominan karena bersifat permanen dan menyebabkan terbentuknya gelombang sinusoidal frekuensi tinggi (kelipatan dari frekuensi fundamental, seperti: $100 \mathrm{~Hz}$, $150 \mathrm{~Hz}, 200 \mathrm{~Hz}, 300 \mathrm{~Hz}$, dan seterusnya). $\mathrm{Hal}$ ini akan mengganggu sistem kelistrikan dengan frekuensi 50/60 (frekuensi fundamental), sehingga bentuk gelombang sinusoidal akan menjadi cacat akibat distorsi harmonisa yang terjadi [2].

\subsection{Total Harmonic Distortion (THD)}

harmonic distortion disebabkan oleh peralatan - peralatan non linier dalam suatu sistem tenaga listrik. Peralatan yang dikategorikan kedalam beban non linier yakni apabila mempunyai output yang nilainya tidak sebanding dengan tegangan yang diberikan [3] .

Persentase THD tegangan dan arus dipersamaankan seperti pada Persamaan berikut [4].

$T H D_{V}=\frac{\sqrt{\sum_{2}^{h} V_{h}^{2}}}{V_{1}} \times 100 \%$

Di mana:

$\mathrm{V}_{\mathrm{h}}=$ Komponen harmonisa tegangan ke-h

$\mathrm{V}_{1}$ = Tegangan frekuensi fundamental (rms)

$T H D_{I}=\frac{\sqrt{\sum_{2}^{h} I_{h}^{2}}}{I_{1}} \times 100 \%$

Di mana:

$\mathrm{I}_{\mathrm{h}}=$ Komponen harmonisa arus ke-h

$\mathrm{I}_{1}=$ Arus frekuensi fundamental (rms)

\subsection{Standar Harmonisa}

Kehadiran harmonisa telah melatarbelakangi terbitnya beberapa standar. Untuk memenuhi kebutuhan standarisasi di atas, Institute of Electrical and Electronics Engineer (IEEE) telah mengeluarkan IEEE Std. 519- 2014. Nilai batas THD arus dapat dilihat pada Tabel 1 [5].

Tabel 1. Batas THD arus menurut standar IEEE 519 tahun 2014

\begin{tabular}{|c|c|c|c|c|c|c|}
\hline $\mathrm{ISC}_{\mathrm{SC}} / \mathrm{L}_{\mathrm{L}}$ & $\begin{array}{c}3 \leq \mathrm{h} \\
\mathbf{\leq} 11\end{array}$ & $\begin{array}{c}11 \leq \\
\mathrm{h} \leq \\
17\end{array}$ & $\begin{array}{c}17 \leq \\
\mathrm{h} \\
\mathbf{2} 23\end{array}$ & $\begin{array}{c}23 \leq \mathrm{h} \\
\leq 35\end{array}$ & $\begin{array}{c}35 \\
\mathrm{~h} \leq \\
50\end{array}$ & THD \\
\hline$<20$ & 4,0 & 2,0 & 1,5 & 0,6 & 0,3 & 5,0 \\
\hline $20<50$ & 7,0 & 3,5 & 2,5 & 1,0 & 0,5 & 8,0 \\
\hline $\begin{array}{c}50< \\
100\end{array}$ & 10,0 & 4,5 & 4,0 & 1,5 & 0,7 & 12, \\
\hline $\begin{array}{c}100 \\
<1000\end{array}$ & 12,0 & 5,5 & 5,0 & 2,0 & 1,0 & 15 \\
\hline$>1000$ & 15,0 & 7,0 & 6,0 & 2,5 & 1,4 & 20,0 \\
\hline
\end{tabular}

Menurut IEEE Std 519 ${ }^{\mathrm{TM}}-2014$ (Revision of IEEE Std 519-1992 ), untuk menentukan standar batas maksimum THDi pada utility, maka harus diketahui terlebih dahulu rasio hubung singkat (shortcircuit ratio). $\mathrm{SC}_{\text {ratio }}$ dapat dihitung menggunakan persamaan [5]:

$\mathrm{SC}_{\text {ratio }}=\frac{I_{S C}}{I_{L}}$

Dimana, Isc (Arus hubung singkat) dapat dihitung dengan persamaan:

$$
\text { ISC }=\frac{K V A \times 100}{\sqrt{3} \times K V \times Z(\%)}
$$


Sedangkan $I_{L}$ (Arus beban maksimum) dapat dihitung dengan persamaan:

$\mathrm{I}_{\mathrm{L}}=\frac{K W}{P F \cdot \sqrt{3} \cdot K V}$

Keterangan :

$\mathrm{I}_{\mathrm{SC}}=$ Arus hubung singkat maksimum pada PCC

$\mathrm{I}_{\mathrm{L}} \quad=$ Arus beban maksimum

$\mathrm{KW}=$ Total daya aktif

Nilai batas untuk THD tegangan dapat dilihat pada Tabel 2 [5].

Tabel 2. Batas THD tegangan menurut standar IEEE 519 tahun 2014

\begin{tabular}{|c|c|c|}
\hline $\begin{array}{c}\text { BusVoltage } \\
\text { at PCC }\end{array}$ & $\begin{array}{c}\text { Individual } \\
\text { Voltage } \\
\text { Distortion } \\
(\%)\end{array}$ & $\begin{array}{c}\text { Total } \\
\text { harmonic } \\
\text { distortion } \\
\text { THD (\%) }\end{array}$ \\
\hline $\begin{array}{c}\mathrm{V} \leq 1,0 \mathrm{kV} \\
\mathrm{kV}<\end{array}$ & 5,0 & 8,0 \\
\hline $\begin{array}{c}69 \mathrm{kV}<\mathrm{V} \leq \\
161 \mathrm{kV}\end{array}$ & 3,0 & 5,0 \\
\hline $161 \mathrm{kV}<\mathrm{V}$ & 1,5 & 2,5 \\
\hline \multicolumn{2}{|r}{} & 1,5 \\
\hline
\end{tabular}

\subsection{Proportional Integral Derivative(PID)}

PID terbagi dari 3 sistem kontrol yaitu kontrol proportional, kontrol integral dan kontrol derivative. Kontrol proportional memiliki keunggulan pada risetime yang cepat kemudian kontrol integral memiliki keunggulan untuk memperkecil error dan kontrol derivative memiliki keunggulan untuk meredam overshot/undershot. Kontrol proportional, integral, dan derivative ini secara terpisah memiliki keunggulannya masing - masing, kemudian untuk mendapatkan keluaran atau hasil dengan risetime yang cepat dan error yang kecil ketiga kontrol tersebut digabungkan menjadi satu kesatuan kontrol yaitu aksi kontrol PID [6].

Parameter pengontrol Proportional Integral derivative (PID) selalu berdasarkan karakteristik plant yang diinginkan. Dalam pencarian parameter PID, perlu diketahui karakteristik atau prilaku dari suatu plant yang dibuat untuk menetukan nilai parameternya [7].

\section{METODE PENELITIAN}

Proses pertama dalam penelitian ini adalah pengumpulan data-data yang berkaitan dengan penelitian yaitu single line diagram, data beban non linier, data THD arus dan THD tegangan pada Bali National Golf Resort. Setelah pengumpulan data, proses selanjutnya melakukan perhitungan yang menyangkut besaran nilai THD arus dan THD tegangan yang sesuai standar serta membandingkan dengan nilai THD arus dan THD tegangan yang didapat dari pengukuran. Pembuatan model simulasi yang akan digunakan pada penelitian, kemudian melakukan simulasi dari model simulasi filter aktif tanpa kontrol PID dan filter aktif menggunakan kontrol PID. Hasil keluaran simulasi filter aktif tanpa kontrol PID dan filter aktif menggunakan kontrol PID dibandingkan dengan hasil pengukuran di Bali National Golf Resort dan standar IEEE 519-2014 sesuai dengan sistem kelistrikan di Bali National Golf Resort.

\section{HASIL DAN PEMBAHASAN}

\subsection{Data hasil pengukuran THDv dan} THDi

Dari hasil pengukuran yang dilakukan pada feeder trafo di panel LVDP PH sampai dengan tujuh panel lainnya akan dilakukan analisis apakah kandungan THD arus dan tegangan telah sesuai dengan standar IEEE 519 Tahun 2014. Data pengukuran dapat dilihat pada Tabel 3.

Tabel 3. Data hasil pengukuran THD arus dan tegangan di Bali Natioanal Golf Resort

\begin{tabular}{|c|c|c|c|}
\hline Tempat & Phasa & $\begin{array}{c}\text { THD }_{1} \\
\text { (\%) }\end{array}$ & $\begin{array}{c}\text { THD }_{V} \\
(\%)\end{array}$ \\
\hline \multirow{3}{*}{ LVDP PH } & $\mathrm{R}$ & 27,5 & 1,9 \\
\hline & $\mathrm{S}$ & 27,10 & 1,6 \\
\hline & $\mathrm{T}$ & 25,96 & 1,5 \\
\hline \multirow{3}{*}{$\begin{array}{l}\text { MDP Power } \\
\text { House }\end{array}$} & $\mathrm{R}$ & 18,9 & 2,2 \\
\hline & $\mathrm{S}$ & 16 & 2,6 \\
\hline & $\mathrm{T}$ & 19,1 & 2 \\
\hline \multirow{3}{*}{$\begin{array}{l}\text { MDP Pump } \\
\text { Station }\end{array}$} & $\mathrm{R}$ & 27,4 & 2,7 \\
\hline & $\mathrm{S}$ & 25,6 & 2,1 \\
\hline & $\mathrm{T}$ & 21,9 & 2,4 \\
\hline \multirow{3}{*}{$\begin{array}{c}\text { LVDP } \\
\text { Subtation D }\end{array}$} & $\mathrm{R}$ & 13,6 & 1,9 \\
\hline & $\mathrm{S}$ & 14,5 & 1,4 \\
\hline & $\mathrm{T}$ & 13,9 & 2,3 \\
\hline \multirow{3}{*}{$\begin{array}{l}\text { MDP Wantilan } \\
\text { Lot } 1\end{array}$} & $\mathrm{R}$ & 15,7 & 1,6 \\
\hline & $S$ & 16,1 & 1,1 \\
\hline & $\mathrm{T}$ & 16,4 & 2 \\
\hline \multirow{3}{*}{$\begin{array}{l}\text { MDP Trinisty } \\
\text { Villa }\end{array}$} & $\mathrm{R}$ & 17,3 & 2,2 \\
\hline & $\mathrm{S}$ & 18 & 1,3 \\
\hline & $\mathrm{T}$ & 18,7 & 2,3 \\
\hline Mdp Golf & $\mathrm{R}$ & 18,3 & 2,4 \\
\hline
\end{tabular}




\begin{tabular}{|c|c|c|c|} 
Course & $\mathrm{S}$ & 19 & 2,1 \\
\cline { 2 - 2 } Maintenannce & $\mathrm{T}$ & 19,7 & 2,1 \\
\hline MDP Lead & $\mathrm{R}$ & 15,4 & 1,9 \\
\cline { 2 - 4 } $\begin{array}{c}\text { Better Golf } \\
\text { Academy }\end{array}$ & $\mathrm{S}$ & 15,1 & 2,1 \\
\cline { 2 - 4 } & $\mathrm{T}$ & 16,8 & 1,6 \\
\hline
\end{tabular}

\subsection{Batas Maksimum THD $_{\mathrm{i}}$ (THD arus)}

Menurut IEEE Std 519 ${ }^{\mathrm{TM}}-2014$ (Revision of IEEE Std 519-1992), untuk menentukan standar batas maksimum THDi, maka harus diketahui terlebih dahulu rasio hubung singkat (short-circuit ratio). $\mathrm{SC}_{\text {ratio }}$ dapat dihitung dengan menggunakan persamaan (3) , (4) dan (5) .

Dari data delapan panel yang didapat pada Bali National Golf Resort, dapat dihitung nilai rasio hubung singkat (shortcircuit ratio). Pada paper ini hanya perhitungan panel LVDP $\mathrm{PH}$ yang akan ditampilkan, dengan meggunakan data panel LVDP PH nilai rasio hubung singkat dapat dihitung sebagai berikut :

$$
\begin{aligned}
& \text { Kapasitas Transformator (kVA) }=400 \mathrm{kVA} \\
& \text { Tegangan Sekunder (kV) } \quad=380 \mathrm{~V} \\
& \text { Impedansi (\%) = } \quad=4 \% \\
& I s c=\frac{k V A \times 100}{\sqrt{3} \times k V \times Z} \\
& =\frac{400 \times 100}{\sqrt{3} \times 0,38 \times 0,04} \\
& =1521143,9 \mathrm{~A} \\
& I_{L}=\frac{K W}{P F \cdot \sqrt{3} \cdot K V} \\
& =\frac{108160}{0,86 \times \sqrt{3} \times 0,38} \\
& =\frac{108160}{0,565364} \\
& =191310,377 \mathrm{~A} \\
& S C_{\text {ratio }}=\frac{I_{S c}}{I_{L}} \\
& =\frac{1521143,9}{191310,377} \\
& =7,952
\end{aligned}
$$

\begin{tabular}{|c|c|c|c|c|}
\hline Tempat & Phasa & $\begin{array}{c}\text { SC ratio } \\
\text { hasil } \\
\text { Perhitu- } \\
\text { ngan }\end{array}$ & $\begin{array}{c}\text { SC } \\
\text { ratio } \\
\text { IEEE } \\
\text { Std } \\
519^{\mathrm{TM}} \\
-2014\end{array}$ & $\begin{array}{c}\text { THD } \\
\text { Max } \\
(\%)\end{array}$ \\
\hline \multirow{3}{*}{ LVDP PH } & $\mathrm{R}$ & 7,952 & $<20$ & 5 \\
\hline & $\mathrm{S}$ & 6,927 & $<20$ & 5 \\
\hline & $T$ & 7,099 & $<20$ & 5 \\
\hline \multirow{3}{*}{$\begin{array}{l}\text { MDP } \\
\text { POWER } \\
\text { HOUSE }\end{array}$} & $\mathrm{R}$ & 17,83 & $<20$ & 5 \\
\hline & $\mathrm{S}$ & 19,027 & $<20$ & 5 \\
\hline & $T$ & 16,854 & $<20$ & 5 \\
\hline \multirow{3}{*}{$\begin{array}{l}\text { MDP PUMP } \\
\text { STATION }\end{array}$} & $\mathrm{R}$ & 12,097 & $<20$ & 5 \\
\hline & $\mathrm{S}$ & 11,62 & $<20$ & 5 \\
\hline & $T$ & 14,124 & $<20$ & 5 \\
\hline \multirow{3}{*}{$\begin{array}{c}\text { LVDP } \\
\text { SUBTATIO } \\
\text { N D }\end{array}$} & $\mathrm{R}$ & 61,147 & $\begin{array}{c}50< \\
100\end{array}$ & 12 \\
\hline & $\mathrm{S}$ & 68,42 & $\begin{array}{c}50< \\
100\end{array}$ & 12 \\
\hline & $\mathrm{T}$ & 55,484 & $\begin{array}{c}50< \\
100\end{array}$ & 12 \\
\hline \multirow{3}{*}{$\begin{array}{c}\text { MDP } \\
\text { WANTILAN } \\
\text { LOT } 1\end{array}$} & $\mathrm{R}$ & 416,16 & $\begin{array}{c}100 \\
<1000 \\
\end{array}$ & 15,0 \\
\hline & $\mathrm{S}$ & 400,19 & $\begin{array}{c}100 \\
<1000 \\
\end{array}$ & 15,0 \\
\hline & $\mathrm{T}$ & 438,55 & $\begin{array}{c}100 \\
<1000\end{array}$ & 15,0 \\
\hline \multirow{3}{*}{$\begin{array}{c}\text { MDP } \\
\text { TRINISTY } \\
\text { VILLA }\end{array}$} & $\mathrm{R}$ & 393,95 & $\begin{array}{c}100 \\
<1000\end{array}$ & 15,0 \\
\hline & $\mathrm{S}$ & 429,14 & $\begin{array}{c}100 \\
<1000\end{array}$ & 15,0 \\
\hline & $\mathrm{T}$ & 374,81 & $\begin{array}{c}100 \\
<1000\end{array}$ & 15,0 \\
\hline \multirow{3}{*}{$\begin{array}{l}\text { MDP GOLF } \\
\text { COURSE } \\
\text { MAINTENA } \\
\text { NNCE }\end{array}$} & $\mathrm{R}$ & 119,98 & $\begin{array}{c}100 \\
<1000 \\
\end{array}$ & 15,0 \\
\hline & $\mathrm{S}$ & 121,87 & $\begin{array}{c}100 \\
<1000\end{array}$ & 15,0 \\
\hline & $\mathrm{T}$ & 123,81 & $\begin{array}{c}100 \\
<1000\end{array}$ & 15,0 \\
\hline
\end{tabular}

Perhitungan SC ratio diatas merupakan hasil perhitungan untuk panel LVDP $\mathrm{PH}$ yang digunakan untuk menentukan batas nilai $T H D_{\text {। }}$ yang diijinkan dengan merujuk standar IEEE 5192014. Sehingga nilai batas maksimum $\mathrm{THD}_{\text {, untuk }}$ kedelapan panel dapat ditentukan dan ditabelkan yang diperlihatkan pada Tabel 4 .

Tabel 4. Batas maksimum $\mathrm{THD}_{\text {, di }}$ Bali National Golf Resort 


\begin{tabular}{|c|c|c|c|c|}
\hline & $\mathrm{R}$ & 324,96 & $\begin{array}{c}100 \\
<1000\end{array}$ & 15,0 \\
\cline { 2 - 5 } $\begin{array}{c}\text { MDP LEAD } \\
\text { BETTER } \\
\text { GOLF }\end{array}$ & $\mathrm{S}$ & 351,24 & $\begin{array}{c}100 \\
<1000\end{array}$ & 15,0 \\
\cline { 2 - 5 } ACADEMY & $\mathrm{T}$ & 308,96 & $\begin{array}{c}100 \\
<1000\end{array}$ & 15,0 \\
\hline
\end{tabular}

perbandingan antara nilai kandungan harmonisa hasil pengukuran dengan hasil perhitungan SC ratio yang merujuk standar IEEE Std 519 ${ }^{\mathrm{TM}}-2014$ untuk menetukan batas nilai $T H D_{1}$ dapat dilihat pada Tabel 5 .

Tabel 5. Perbandingan $\mathrm{THD}_{\mathrm{I}}$ pengukuran dengan standar IEEE Std 519 ${ }^{\mathrm{TM}}$. 2014

\begin{tabular}{|c|c|c|c|c|}
\hline Tempat & $\begin{array}{c}\text { Phas } \\
\text { a }\end{array}$ & $\begin{array}{c}\text { THD } \\
\text { pada } \\
\text { Bali } \\
\text { National } \\
\text { Golf } \\
\text { Resort } \\
(\%) \\
\end{array}$ & $\begin{array}{c}\text { THD }_{\text {I }} \\
\text { sesuai } \\
\text { IEEE } \\
\text { Std } \\
519^{\text {TM_ }} \\
2014 \\
(\%) \\
\end{array}$ & KET \\
\hline \multirow{3}{*}{ LVDP PH } & $\mathrm{R}$ & 27,5 & 5 & $\begin{array}{c}\text { Tidak } \\
\text { standar }\end{array}$ \\
\hline & $\mathrm{S}$ & 27,10 & 5 & $\begin{array}{c}\text { Tidak } \\
\text { standar }\end{array}$ \\
\hline & $\mathrm{T}$ & 25,96 & 5 & $\begin{array}{c}\text { Tidak } \\
\text { standar }\end{array}$ \\
\hline \multirow{3}{*}{$\begin{array}{l}\text { MDP } \\
\text { POWER } \\
\text { HOUSE }\end{array}$} & $\mathrm{R}$ & 18,9 & 5 & $\begin{array}{c}\text { Tidak } \\
\text { standar }\end{array}$ \\
\hline & $\mathrm{S}$ & 16 & 5 & $\begin{array}{c}\text { Tidak } \\
\text { standar }\end{array}$ \\
\hline & $\mathrm{T}$ & 19,1 & 5 & $\begin{array}{c}\text { Tidak } \\
\text { standar }\end{array}$ \\
\hline \multirow{3}{*}{$\begin{array}{l}\text { MDP PUMP } \\
\text { STATION }\end{array}$} & $\mathrm{R}$ & 27,4 & 5 & $\begin{array}{c}\text { Tidak } \\
\text { standar }\end{array}$ \\
\hline & $\mathrm{S}$ & 25,6 & 5 & $\begin{array}{c}\text { Tidak } \\
\text { standar }\end{array}$ \\
\hline & $\mathrm{T}$ & 21,9 & 5 & $\begin{array}{c}\text { Tidak } \\
\text { standar }\end{array}$ \\
\hline \multirow{3}{*}{$\begin{array}{c}\text { LVDP } \\
\text { SUBTATIO } \\
\text { N D }\end{array}$} & $\mathrm{R}$ & 13,6 & 12 & $\begin{array}{c}\text { Tidak } \\
\text { standar }\end{array}$ \\
\hline & $\mathrm{S}$ & 14,5 & 12 & $\begin{array}{c}\text { Tidak } \\
\text { standar }\end{array}$ \\
\hline & $\mathrm{T}$ & 13,9 & 12 & $\begin{array}{c}\text { Tidak } \\
\text { standar }\end{array}$ \\
\hline \multirow{3}{*}{$\begin{array}{c}\text { MDP } \\
\text { WANTILAN } \\
\text { LOT } 1\end{array}$} & $\mathrm{R}$ & 15,7 & 15,0 & $\begin{array}{c}\text { Tidak } \\
\text { standar }\end{array}$ \\
\hline & $\mathrm{S}$ & 16,1 & 15,0 & $\begin{array}{c}\text { Tidak } \\
\text { standar }\end{array}$ \\
\hline & $\mathrm{T}$ & 16,4 & 15,0 & $\begin{array}{c}\text { Tidak } \\
\text { standar }\end{array}$ \\
\hline \multirow{3}{*}{$\begin{array}{c}\text { MDP } \\
\text { TRINISTY } \\
\text { VILLA }\end{array}$} & $\mathrm{R}$ & 17,3 & 15,0 & $\begin{array}{c}\text { Tidak } \\
\text { standar }\end{array}$ \\
\hline & $\mathrm{S}$ & 18 & 15,0 & $\begin{array}{c}\text { Tidak } \\
\text { standar }\end{array}$ \\
\hline & $\mathrm{T}$ & 18,7 & 15,0 & $\begin{array}{c}\text { Tidak } \\
\text { standar }\end{array}$ \\
\hline \multirow{2}{*}{$\begin{array}{l}\text { MDP GOLF } \\
\text { COURSE } \\
\text { MAINTENA }\end{array}$} & $\mathrm{R}$ & 18,3 & 15,0 & $\begin{array}{c}\text { Tidak } \\
\text { standar }\end{array}$ \\
\hline & $\mathrm{S}$ & 19 & 15,0 & Tidak \\
\hline
\end{tabular}

\begin{tabular}{|c|c|c|c|c|}
\hline NNCE & & & & standar \\
\cline { 2 - 5 } & $\mathrm{T}$ & 19,7 & 15,0 & $\begin{array}{c}\text { Tidak } \\
\text { standar }\end{array}$ \\
\hline $\begin{array}{c}\text { MDP LEAD } \\
\text { BETTER } \\
\begin{array}{c}\text { GOLF } \\
\text { ACADEMY }\end{array}\end{array}$ & $\mathrm{R}$ & 15,4 & 15,0 & $\begin{array}{c}\text { Tidak } \\
\text { standar }\end{array}$ \\
\cline { 2 - 5 } & $\mathrm{T}$ & 15,1 & 15,0 & $\begin{array}{c}\text { Tidak } \\
\text { standar }\end{array}$ \\
\cline { 2 - 5 } & $\mathrm{T}$ & 16,8 & 15,0 & $\begin{array}{c}\text { Tidak } \\
\text { standar }\end{array}$ \\
\hline
\end{tabular}

\subsection{Simulasi Pengunaan PID Controller} Filter aktif untuk mengurangi Total Harmonic Distorsion (THD).

Model rangkaian pada simulasi MATLAB dimana telah terpasangnya filter aktif shunt pada simulasi, dari delapan panel yang terdapat dalam penelitian ini, pada penelitian ini desain model simulink dan hasil simulasi yang ditampilkan hanya panel LVDP PH. Gambar model simulink dapat dilihat pada Gambar 1.

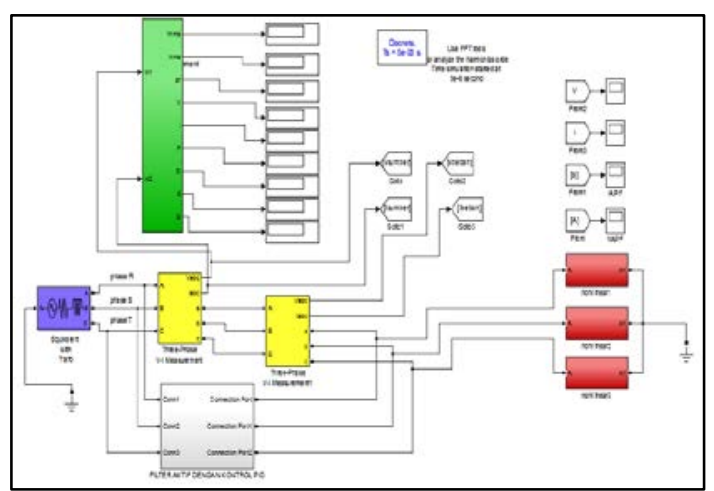

Gambar 1. Desain model Simulink filter aktif dengan kontrol PID

Dengan bantuan FFT Tools dapat diketahui besarnya kandungan THD pada sinyal dan spectrum yang dihasilkan oleh simulasi pada sistem, untuk hasil simulasi THDi setelah pengoperasian filter aktif dapat dilihat pada Gambar 2.

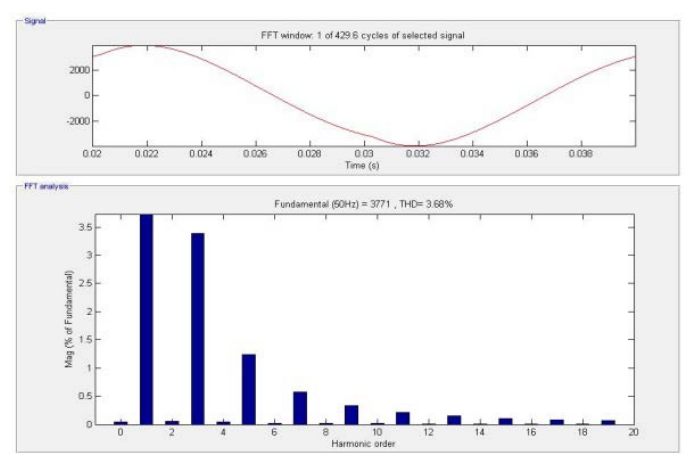

Gambar 2. Hasil Simulasi THDi setelah pengoperasian filter aktif 
Hasil simulasi THDv setelah pengoperasian filter aktif dapat dilihat pada Gambar 3.

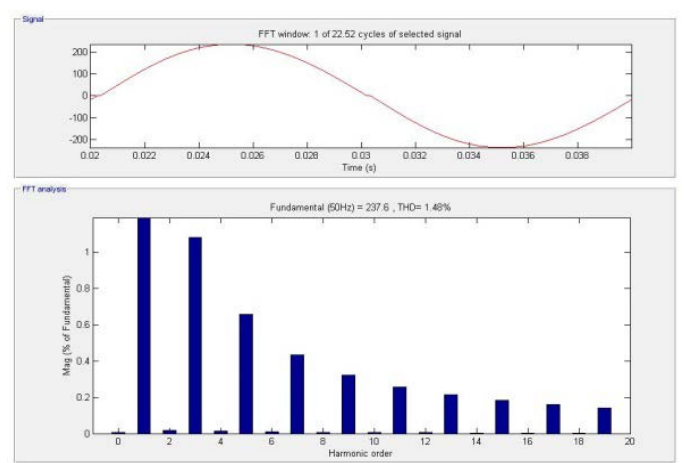

Gambar 3. Simulasi THDv setelah pengoperasian filter aktif

Hasil Simulasi $T H D_{1}$ setelah pengoperasian filter aktif dengan kontrol PID dapat dilihat pada Gambar 4.

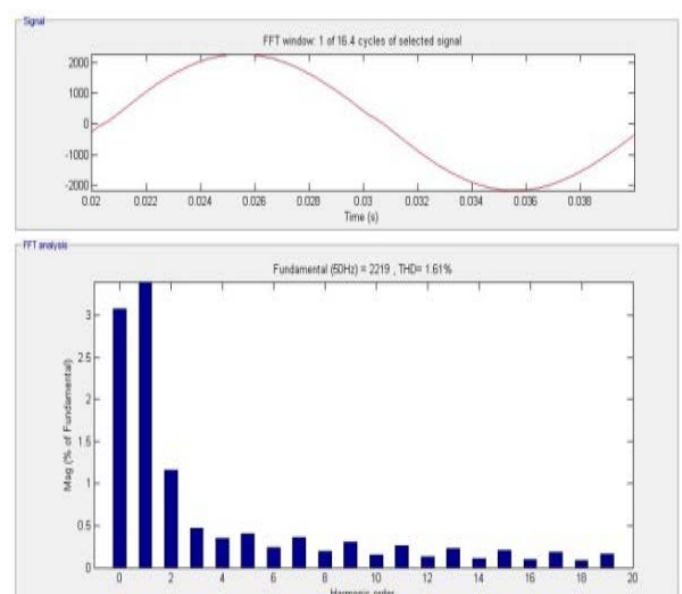

Gambar 4. Hasil Simulasi THDi setelah pengoperasian filter aktif dengan kontrol PID

Hasil Simulasi $\mathrm{THD}_{\mathrm{v}}$ setelah pengoperasian filter aktif dengan kontrol PID dapat dilihat pada Gambar 5.

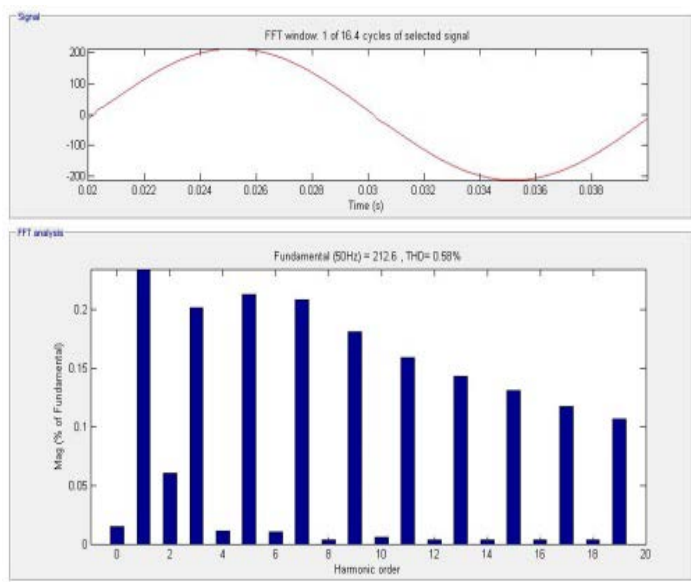

Gambar 5. Hasil Simulasi THDv setelah pengoperasian filter aktif dengan kontrol PID

4.4 Analisis Perbandingan Simulasi THD Menggunakan Filter Aktif Tanpa Kontrol dengan Filter Aktif Menggunakan PID Controller

Perbandingan hasil setiap simulasi yang telah dilakukan untuk ke-delapan panel yang terdapat pada penelitian ini, dapat dilihat pada Tabel 6 .

Tabel 6. Perbandingan Hasil Simulasi THDi dan THDv Setiap Simulasi

\begin{tabular}{|c|c|c|c|c|c|}
\hline \multirow{2}{*}{ Tempat } & \multirow{2}{*}{ Phasa } & \multicolumn{2}{|c|}{$\begin{array}{c}\text { Filter aktif } \\
\text { tanpa } \\
\text { kontrol }\end{array}$} & \multicolumn{2}{|c|}{$\begin{array}{c}\text { Filter aktif } \\
\text { dengan } \\
\text { kontrol PID }\end{array}$} \\
\hline & & $\begin{array}{l}\text { THD } \\
(\%)\end{array}$ & $\begin{array}{l}\mathrm{THD}_{\mathrm{v}} \\
(\%)\end{array}$ & $\begin{array}{l}\mathrm{THD}_{1} \\
(\%)\end{array}$ & $\begin{array}{c}\text { THDv } \\
(\%)\end{array}$ \\
\hline \multirow{3}{*}{ LVDP PH } & $\mathrm{R}$ & 3,68 & 1,48 & 1,61 & 0,58 \\
\hline & $\mathrm{S}$ & 4,28 & 1,74 & 1,90 & 0,60 \\
\hline & $\mathrm{T}$ & 4,12 & 1,66 & 1,58 & 0,59 \\
\hline \multirow{3}{*}{$\begin{array}{l}\text { MDP } \\
\text { POWER } \\
\text { HOUSE }\end{array}$} & $\mathrm{R}$ & 1,77 & 0,75 & 1,50 & 0,7 \\
\hline & $\mathrm{S}$ & 1,71 & 0,62 & 1,66 & 0,62 \\
\hline & $\mathrm{T}$ & 2,04 & 0,73 & 1,64 & 0,66 \\
\hline \multirow{3}{*}{$\begin{array}{l}\text { MDP PUMP } \\
\text { STATION }\end{array}$} & $\mathrm{R}$ & 4,06 & 1,46 & 3,29 & 1,37 \\
\hline & $\mathrm{S}$ & 4,52 & 1,49 & 3,61 & 1,47 \\
\hline & $\mathrm{T}$ & 3,20 & 1,03 & 2,36 & 0,93 \\
\hline \multirow{3}{*}{$\begin{array}{c}\text { LVDP } \\
\text { SUBTATION } \\
\text { D }\end{array}$} & $\mathrm{R}$ & 3,55 & 0,56 & 2,10 & 0,41 \\
\hline & $\mathrm{S}$ & 4,14 & 0,69 & 2,33 & 0,45 \\
\hline & $\mathrm{T}$ & 3,67 & 0,68 & 1,73 & 0,44 \\
\hline \multirow{3}{*}{$\begin{array}{c}\text { MDP } \\
\text { WANTILAN } \\
\text { LOT } 1\end{array}$} & $\mathrm{R}$ & 3,33 & 0,8 & 1,57 & 0,33 \\
\hline & $\mathrm{S}$ & 3,42 & 0,9 & 1,52 & 0,43 \\
\hline & $T$ & 3,29 & 0,81 & 0,90 & 0,26 \\
\hline \multirow{3}{*}{$\begin{array}{c}\text { MDP } \\
\text { TRINISTY } \\
\text { VILLA }\end{array}$} & $\mathrm{R}$ & 3,55 & 0,9 & 1,58 & 0,34 \\
\hline & $\mathrm{S}$ & 3,13 & 0,88 & 1,57 & 0,42 \\
\hline & $\mathrm{T}$ & 3,99 & 0,85 & 0,96 & 0,28 \\
\hline \multirow{2}{*}{$\begin{array}{l}\text { MDP GOLF } \\
\text { COURSE }\end{array}$} & $\mathrm{R}$ & 2,66 & 0,83 & 2,56 & 0,80 \\
\hline & $\mathrm{S}$ & 2,64 & 0,84 & 2,61 & 0,82 \\
\hline
\end{tabular}




\begin{tabular}{|c|c|c|c|c|c|}
\hline $\begin{array}{l}\text { MAINTENAN } \\
\text { NCE }\end{array}$ & $\mathrm{T}$ & 2,73 & 0,83 & 2,27 & 0,69 \\
\hline \multirow{3}{*}{$\begin{array}{c}\text { MDP LEAD } \\
\text { BETTER } \\
\text { GOLF } \\
\text { ACADEMY }\end{array}$} & $R$ & 1,68 & 0,38 & 1,66 & 0,32 \\
\hline & $\mathrm{S}$ & 1,71 & 0,45 & 1,67 & 0,33 \\
\hline & $\mathrm{T}$ & 1,50 & 0,32 & 1,08 & 0,29 \\
\hline
\end{tabular}

Dari tabel diatas terlihat kandungan THDi setelah pemasangan filter aktif tanpa kontrol terjadi penurununan nilai THDi dimana dengan jumlah penurunan tersebut sudah memenuhi standar IEEE 519 Tahun 2014. Tercatat THDi tertinggi pada MDP Pump Station Phasa S dengan kandungan THDi sebesar 4,52 \% dan Kandungan THDi terendah sebesar 1,5\% terdapat pada MDP Lead Better Golf Academy.

Kandungan THDv pada setiap panel di Bali National Golf Resort sesuai pengukuran di lapangan telah memenuhi standar dengan batas THDv sebesar $\leq 5,0$ $\%$. Mengacu pada tabel 4.8 dan tabel 4.10 terjadi penurunan nilai THDV setelah pemasangan filter aktif tanpa kontrol dimana nilai THDv tertinggi terdapat pada LVDP $\mathrm{PH}$ sebesar 1,74\% dan terendah terdapat pada MDP Lead Better Golf Academy Phasa T sebesar 0,32 \%

Kandungan THDi setelah pemasangan filter aktif dengan kontrol PID terjadi penurununan nilai THDi dimana dengan jumlah penurunan tersebut sudah memenuhi standar IEEE 519 Tahun 2014. Tercatat THDi tertinggi pada MDP Pump Station Phasa $\mathrm{S}$ dengan kandungan THDi sebesar 3,61 \% dan Kandungan THDi terendah sebesar $0,90 \%$ terdapat pada MDP Trinisty Villa Phasa T.

Untuk THDv setelah pemasangan filter aktif dengan kontrol PID terjadi penurunan nilai THDv dimana nilai THDv tertinggi terdapat pada MDP Pump Station Phasa S sebesar $1,47 \%$ dan terendah terdapat pada MDP Lead Better Golf Academy Phasa T sebesar 0,29\%.

\section{KESIMPULAN}

Berdasarkan hasil analisis penggunaan proportional integral derivative (PID) controller pada filter aktif untuk meredam harmonisa akibat beban non linier di Bali National Golf Resort, maka simpulan yang didapatkan adalah Kandungan $\mathrm{THD}_{\mathrm{i}}$ setelah penggunaan filter aktif tanpa kontrol turun rata-rata menjadi $3,099 \%$. Untuk kandungan $\mathrm{THD}_{\vee}$ turun rata-rata menjadi $0,904 \%$. Kemudian
Kandungan $\mathrm{THD}_{i}$ setelah penggunaan filter aktif dengan kontrol PID turun rata-rata menjadi 1,884\%. Untuk kandungan $\mathrm{THD}_{V}$ turun rata-rata menjadi $0,589 \%$. sehingga penggunaan filter aktif dengan kontrol PID lebih baik karena mampu menghasilkan nilai THD yang lebih kecil.

\section{DAFTAR PUSTAKA}

[1] A. I. Weking, I. W. Rinas, and A. K. Suwardana, "Simulasi Penentuan Penempatan Filter Aktif Shunt Untuk Mendapatkan Distorsi Daya Yang Terkecil Di Blue Point Bay Villa \& Spa," Maj. IIm. Teknol. Elektro, vol. 12, no. 2, 2013.

[2] R. C. Dugan, M. F. McGranaghan, S. Santoso, and H. W. Beaty, Electrical Power System Quality-Second Edition. USA: McGraw-Hill, 2003.

[3] I. W. Rinas, "Simulasi Penggunaan Filter Pasif, Filter Aktif dan Filter Hybrid Shunt untuk Meredam Meningkatnya Distorsi Harmonisa yang Disebabkan Oleh Munculnya Gangguan Resonansi," Maj. Ilm. Teknol. Elektro, vol. 12, no. 2, 2013.

[4] I. G. A. Gunawan, I. W. Rinas, and I. W. A. Wijaya, "ANALISIS DISTORSI HARMONISA PADA PENYULANG ABANG KARANGASEM SE ${ }^{\mathrm{TH}} \mathrm{AH}$ TERPASANGNYA PEMBANGKIT LISTRIK TENAGA SURYA (PLTS)," J. IIm. SPEKTRUM, vol. 2, no. 3, pp. 130-135.

[5] IEEE Standards Association, "IEEE recommended practices and requirements for harmonic control in electrical power systems," 2014.

[6] S. Omatu, M. Yoshioka, T. Kosaka, H. Yanagimoto, and J. A. Dargham, "Neuro-PID Control of Speed and Torque of Electric Vehicle," Int. J. Adv. Syst. Meas. Vol. 3 Number 12 2010, 2010.

[7] K. H. Ang, G. Chong, and Y. Li, "PID control system analysis, design, and technology," IEEE Trans. Control Syst. Technol., vol. 13, no. 4, pp. 559-576, 2005. 